\title{
İole bir dental klinikte ultrasonik skaler kullanımı sonrası oluşan aerosol kontaminasyonunun gözlenmesi
}

\author{
Sefa Aydındoğan(0000-0003-2980-2691 ${ }^{\alpha}$, Zafer Sayın(0000-0001-6096-4440) ${ }^{\beta}$, İsmail Marakoğlu(0000-0002-9869-7883) ${ }^{\alpha}$ \\ Selcuk Dent J 2020: 7: 373-378 (Doi: 10.15311/selcukdentj. 782580)_ Bassvuru Tarihi: 19 Ağustos 2020 \\ Yayına Kabul Tarihi: 05 Kasım 2020
}

öz

İzole bir dental klinikte ultrasonik skaler kullanımı sonrası oluşan aerosol kontaminasyonunun gözlenmesi

Amaç: Dental tedaviler sırasında önemli miktarda mikrobiyal aerosol ortaya çıkmaktadır. Aerosoller diş hekimi, dental personel ve hasta arasında enfeksiyonun yayılımında önemli yer tutmaktadır. Bu çalışmanın amacı ultrasonik skaler kullanımına bağlı oluşan total bakteriyel aerosol kontaminasyonlarının farklı zaman aralıklarında değerlendirilmesidir.

Gereç ve Yöntemler: Kliniğimize rutin periodontal tedavi için başvuran benzer ağız içi kondisyonlara sahip 7 hastanın başlangıç periodontal tedavisi, izole bir tedavi odasında ultrasonik skaler kullanılarak yapıldı. Tedavi öncesi, tedavinin hemen sonrası ve tedavi sonrası 2 saate kadar $15 \mathrm{dk}$ aralıklarla hava örnekleri alındı. Hava örneklemesi, aktif hava örnekleme cihazı kullanılarak yapıldı (Biomerieux Air Ideal, France). Total bakteriyel konsantrasyonun belirlenmesi amaciyla PCA (Plate Count Agar) besiyeri kullanıldı. $37^{\circ} \mathrm{C}$ 'de 48 saat inkübasyon sonrası CFU (colony forming ünit) sayımı yapıldı.

Bulgular: Tedavi sonrasında, öncesine göre aerosol kontaminasyonunun istatistiksel olarak anlamlı şekilde yüksek olduğu görüldü $\left(230,429 \pm 60,458 \mathrm{CFU} / \mathrm{m}^{3}-780,143 \pm 130,979\right.$ $\left.\mathrm{CFU} / \mathrm{m}^{3}\right)(\mathrm{p}<0,05)$. Kontaminasyonun tedavi hemen sonrasında pik değerlerine ulaştığı ve saçılan aerosollerin 60 dk' ya kadar ortamda kaldığı sonrasında istatistiksel olarak anlamlı olarak azalmaya başladığı görüldü $(p<0,05)$. Tedaviden 75,90 ve 120 dk sonrasında alınan hava örnekleriyle tedavi öncesi alınan örnekler arasında fark olmadığı görüldü.

Sonuç: Periodontal tedaviler sırasında önemli oranda aerosol kontaminasyonu oluşmakta ve ortamda uzun süre varlığını devam ettirmektedir. Bu durum aerosolle bulaşa sahip hastalıkların çapraz enfeksiyonunda önemli bir yer tutmaktadır.

\section{ANAHTAR KELIMELER}

Aerosol, aktif hava örnekleme, ultrasonik skaler, periodontal tedavi, mikrobiyal aktivite

Periodontitis tedavisi temel olarak supra ve subgingival alanlardaki patojenlerin azaltılmasını amaçlamaktadır. Periodontal cep içerisinin mekanik debridmanı ile gingival sağlığın oluşturulmasında önemli gelişmeler sağlanmaktadır. ${ }^{1}$ Geleneksel periodontal el aletleri ve ultrasonik skalerların birbirine göre klinik olarak üstünlükleri gösterilemese de kullanım kolaylığı ve daha az zaman gerektirmesi gibi avantajları dolayısıyla ultrasonik el aletleri klinisyenler tarafından giderek

\section{ABSTRACT}

Monitoring of aerosol contamination after use of ultrasonic scaler in an isolated dental clinic

Background: During dental treatments, a significant amount of microbial aerosols appear. Aerosols have an important place in the spread of infection between the dentist, dental staff and the patient. The aim of this study is to evaluate the total bacterial aerosol contamination due to use of ultrasonic scaler at different time intervals.

Methods: The initial periodontal treatment of patients with similar intra-oral conditions who applied to our clinic for routine periodontal treatment was performed using an ultrasonic scaler in an isolated treatment room.. Air samples were taken before, and after treatment (15 minutes time-intervals up to 2 hours) using active air sampling device (Biomerieux Airldeal, France). PCA(Plate Count Agar) medium was used to determine the total bacterial concentration. CFU(colony forming unit) count was performed after at $37^{\circ} \mathrm{C}$ - 48 hours incubation.

Results: After treatment, aerosol contamination was statistically significantly higher than before $\left(230,429 \pm 60,458 \mathrm{CFU} / \mathrm{m}^{3}\right.$ $\left.780,143 \pm 130,979 \mathrm{CFU} / \mathrm{m}^{3}\right)(p<0.05)$. It was seen that the contamination reached peak values immediately after the treatment and the scattered aerosols remained in the air for up to 60 minutes and then decreased statistically significantly $(p<$ $0.05)$. There was no difference between the air samples taken 75,90 and 120 minutes after the treatment and the samples taken before the treatment.

Conclusion: Significant aerosol contamination occurs during periodontal treatments and persists in the environment for a long time. This situation plays an important role in the cross infection of aerosol-borne diseases.

\section{KEYWORDS}

Aerosol, active air sampling, ultrasonic scaler, periodontal treatment, microbial activity

daha fazla tercih edilmektedir. ${ }^{2,3}$ Ultrasonik skalerlar ve diş hekimliğinde kullanılan diğer hava türbünlü el aletleri oral mikroorganizmalarla kontamine bir aerosol bulutu oluşturmaktadır. Dental tedaviler sonrasında gözle görülebilen önemli miktarda aerosol oluşumu bu konudaki endişeleri artırmaktadır. ${ }^{4}$

Hava türbünlü el aletlerininin itici gücü ve kavitasyon etkisi, ilave olarak soğutma suyu kullanımının da

\footnotetext{
${ }^{\alpha}$ Selçuk Üniversitesi, Diş Hekimliği Fakültesi, Periodontoloji Anabilim Dalı, Konya

${ }^{\beta}$ Selçuk Üniversitesi, Veteriner Fakültesi, Mikrobiyoloji Anabilim Dalı, Konya
} 
eklenmesiyle kan, tükürük, dental debris, dental plak, diş taşı ve restoratif materyallerden kaynaklanan çok sayıda küçük partikülün ortama şaçılmasına neden olmaktadır. $^{5}$

Dental çerçevede 'aerosol' ve 'splatter' kavramları ise Micik ve arkadaşlarının yaptığı öncü çalışmada tanımlanmıştır. Bu çalışmaya göre aerosol $50 \mu \mathrm{m}$ çapından daha küçük parçacıklar olarak tanımlanmaktadır. Bu tür parçacıklara 'damlacık çekirdeği' denilmektedir. ${ }^{6}$ Bu parçacıklar çevresel yüzeylere yapışmadan veya solunum sistemine girmeden önce uzun süre havada asılı kalacak kadar küçüktür. İnhalasyon yoluyla insan vücuduna girebilmektedir ve sağlığı tehdit eden ciddi enfeksiyon yayılımlarına yol açabilmektedirler. ${ }^{7} \quad$ Splatter (damlacık) ise havada dağılan $50 \mu \mathrm{m}$ çapından daha büyük parçacıklar olarak tanımlanmıştır. $\mathrm{Bu}$ parçacıklar balistik tarzda hareket ederler. Bu durum parçacık veya damlacıkların çalışma bölgesinden uzaklaşıtıktan sonra bir yüzeye temas edene veya yere düşene kadar bir mermininkine benzer bir yörüngede bir yay çizdiği anlamına gelir. Bu parçacıklar havada asılı kalamayacak kadar büyüktür ve havada kaldıkları süre oldukça azdır. İnhale edilemeyecek kadar büyüktürler. Çevresel yüzeylere sıçrayarak yapışma eğilimindedirler. ${ }^{7}$ Aerosolün daha küçük parçacıkları (0,5-10 $\mu \mathrm{m}$ çapa sahip olanlar) akciğerlerin terminal alanlarına nüfuz etme ve yerleşme potansiyeline sahiptir. Aynı zamanda bu partiküllerin enfeksiyon yayılımı için en büyük potansiyele sahip oldukları düşünülmektedir. ${ }^{8}$ Dental tedaviler sırasında küçük partiküllerin $(<0,5 \mu \mathrm{m})$, büyük partiküllere göre $(>0,5 \mu \mathrm{m})$ daha fazla oluştuğuna yönelik çalışmalar mevcuttur. ${ }^{9}$

Aerosoller solunum yolu enfeksiyonları, göz ve deri rahatsızlıkları, tüberküloz ve lejyonelloz gibi enfeksiyoz hastalıkların oluşumunda etken olmaktadır. Ayrıca hepatit $B$ ve influenza gibi viral enfeksiyonların yayılımında da önemlidir. 8,10 Burun tıkanıklığı, göz irritasyonları ve baş ağrıları da rapor edilmiştir. ${ }^{11}$ Total bakteriyel aerosol konsantrasyonu dış ortamın havası, havalandırma tipi, sıklığı, iç ortamın nemi gibi birçok faktöre bağlıdır. ${ }^{12}$ Ayrıca dental işlem sonrası oluşan aerosol kontaminasyonu hastanın ağız içi kondisyonları, tedavi odasının şekli ve hacmi, kullanılan el aletleri, soğutma suyu gibi faktörlere bağı olarak da farklılık gösterebilir.

Dental tedaviler genellikle işlem sırasında ortaya çıkan nem dolayısıyla durağan bir havaya sahip küçük tedavi odalarında yapılmaktadır. Ek olarak potansiyel çevresel risk taşıyan aerosol kontaminasyonuna sebep olan işlemler yapılmaktadır. ${ }^{5}$ Oluşan aerosol konsantrasyonlarının ve bunların sirkülasyonlarının anlaşılması, dental personele ortaya çıkan aerosollerin azaltılmasında ve önlemler alınmasında yardımcı olacaktır. Bu çalışmanın amacı aynı klinik ortamda benzer ağız içi kondisyonlara sahip olan hastalarda ultrasonik skaler kullanımına bağlı olarak oluşan aerosol konsantrasyonlarının değişiminin tedavi öncesi, tedavi sırası ve tedavi sonrası belirli zaman aralıklarında değerlendirilmesidir.

\section{GEREÇ VE YÖNTEM}

Selçuk Üniversitesi Diş Hekimliği Fakültesi Periodontoloji kliniğine rutin diştaşı temizliği için başvuran 7 yazıı ınam alınmış hasta çalışmaya dahil edildi. Çalıșmaya dahil edilme kriterleri olarak tüm ağız ortalama plak indeksi 1-2 arasında olması, periodontal olarak plağa bağlı gingivitis tanısı koyulmuş olması, sistemik olarak sağlıklı olmak, en az 20 daimi dişe sahip olmak olarak belirlendi. Çalışmaya dahil edilmeme kriterleri ise son 1 ay içerisinde sistemik/topikal etkili herhangi bir antibiyotik veya antiseptik kullanmak, ağızda aktif çürük lezyonu bulunması, kalp pili olmak, solunum yolu problemi olmak, hamile veya laktasyon döneminde olmak, sigara içmek, ağıziçi sert veya yumuşak doku lezyonuna sahip olmak, dental tedavi girişimleri sırasında antibiyotik profilaksisi gerektiren sistemik hastalık veya durumlara sahip olmak olarak belirlendi. Bu kriterlere sahip bireyler çalışma dışı bırakıldı.

Çalışmaya dahil edilen bireylerin başlangıç periodontal tedavileri poliklinik ortamından izole, tek dental ünite sahip olan aynı tedavi odasında yapıldı. Tedavi odasının bulunduğu klinikte tedavi süresince başka hasta bakılmadı. Her tedavi öncesinde $15 \mathrm{dk}$ süre entegre havalandırma sistemiyle ve aynı güç ile ortam havalandırması yapıldı. Hava dolaşımı sağlandı. Tedavi sırasında dış ortam kontaminasyonunu en aza indirmek amacı ile tedavi odasının kapısı kapalı tutuldu. Tedavi sonrasında ise klinik simülasyonu sağlaması amaçlanarak oda kapısı açılarak havalanmasına olanak verildi. Tedavi sonrasında 2 saat süresince tedavi odasına giriş-çıkışlar sınırlandırıldı ve sadece hava örnekleri alınması için giriş-çıkış sağlandı. Çalışmada izole bir dental tedavi odasında başlangıç periodontal tedavi için ultrasonik skaler kullanımı sonrasında oluşan aerosol kontaminasyonunun zamana bağlı değişiminin belirlenmesi amaçlanmıştır. Aerosol kontaminasyonunun değerlendirilmesi için aktif hava örnekleme yöntemiyle, bir hava örnekleyici cihaz kullanılarak hava örnekleri alındı (Biomerieux Airideal, France). Kullanılan hava örnekleme cihazı impaction prensibi ile çalışmakta ve havadaki mikroorganizmaları, hava akımı ile cihaz üzerine yerleştirilen besiyerine otomatik ekim yapabilmektedir. ${ }^{13} 100 \mathrm{lt} / \mathrm{dk}$ sabit debi ile hava vakumu yapmaktadır. Farklı çalışma modlarında çalışabilmekte ve süresi ayarlanabilmektedir. Değiştirilebilir ve steril edilebilir hava filtreleri bulunmaktadır. Mikroorganizmaların değerlendirilmesinde ağız içerisinde en çok aerobik bakterilerin bulunması dolayısıyla total bakteri sayısının değerlendirilmesinde kullanılan Plate Count Agar (PCA) besiyeri kullanıldı. 
Çalışmada her hastada aynı tip ultrasonik skaler ve skaler ucu kullanıldı (P5 Newtron, Acteon Satellec, Germany). Her hastada aynı ultrasonik güç ayarı kullanılarak işlem gerçekleştirildi. Soğutma suyunun her hastada standardizasyonu soğutma suyu paneline koyulan bir işaretleme yardımı ile sağlandı. Her hastada aynı konvalsiyonel dental tükürük emici ağız köşelerinde konumlandırılarak ağızdan su tahliyesinin eşit koşullarda yapılması sağlandı. Ultrasonik skaler kullanılarak yapılan diş taşı temizliği sırasında hava örnekleme cihazı ile hava çekilerek, cihaz içerisine yerleşik bulunan besiyerine (PCA) bakteriyel ekim yapıldı. Diş taşı temizliği maksimum $30 \mathrm{dk}$ tedavi süresince yapıldı ve kazıyıcı ucun mümkün olan en uzun süre ağız içi kullanımda kalması sağlandı. Hava örnekleme cihazı, hasta ağzından yatay düzlemde 100 cm uzaklıkta, yerden $100 \mathrm{~cm}$ yükseklikte konumlandırıldı, $1 \mathrm{dk}$ süre ile (sabit debi ile $100 \mathrm{lt}$ ) hava örnekleri toplandı (Şekil 2). Örnekler tedavi öncesi, tedavi sırası, tedavi hemen sonrası ve $15 \mathrm{dk}$ aralıklarla 120 dk'ya kadar alındı (tedavi sonrası 15, 30, 45, 60, $75,90,105,120 \mathrm{dk})$.

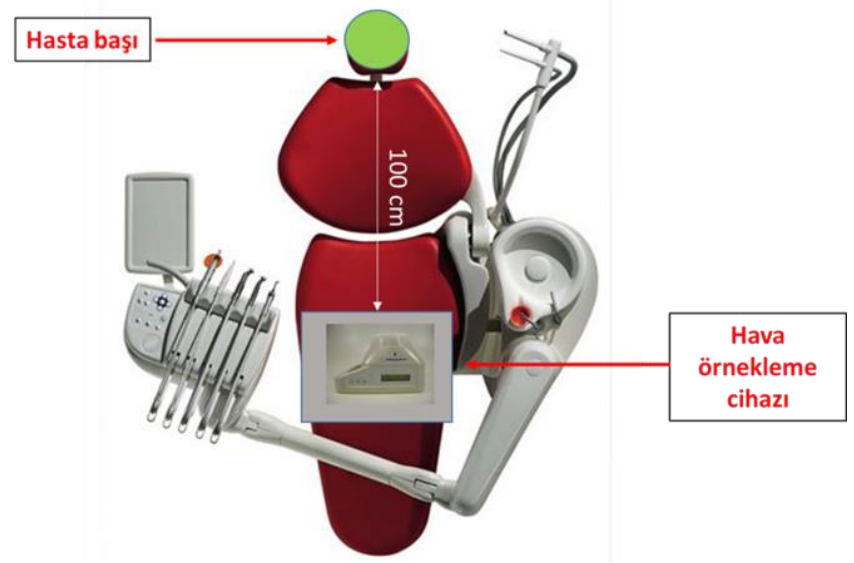

Şekil 2

Hava örnekleyici cihaz ve açık besiyerinin hasta başına göre konumunun gösterilmesi grafiği $(n=10)$

Hava örnekleri uygun koşullarda korunarak, Selçuk Üniversitesi Veteriner Fakültesi Mikrobiyoloji laboratuvarında inkübatöre konuldu. $37^{\circ}$ de 48 saat inkübe edildi ve CFU sayımı kontaminasyon önlemleri alınarak, uygun ışıklandırma altında mikrobiyolog rehberliğinde gözle yapıldı.

Verilerin değerlendirilmesinde SPPS 25 (IBM Corp. Released 2017. IBM SPSS Statistics for Windows, Version 25.0. Armonk, NY: IBM Corp.) istatistik paket programı kullanılmıştır. Değişkenler ortalama \pm standart sapma ve Medyan (MaksimumMinimum) yüzde ve frekans değerleri kullanılmıştır. Verilerin tekrarlanan ölçümler varyans analizine uygunluğu Mauchy's Küresellik Testi ve Box-M Varyansların Homojenliği Testi ile değerlendirilmiştir.
Ortalamaların karşılaştırmaları için faktöriyel düzende faktörlerden biri tekrarlanan ölçümler varyans analizi kullanılmıştır. Eğer parametrik testlerin (faktöriyel düzende tekrarlanan ölçümler varyans analizi) ön şartlarını sağlamıyorsa serbestlik derecesi düzeltmeli Greenhouse-Geisser (1959) ya da Huynh-Feldt (1976) testlerinden biri kullanılmıştır. Çoklu karşılaştırmalar ise Düzeltilmiş Bonferroni Testi ile gerçekleştirilmiştir. Testlerin anlamlılık düzeyi için $p<0,05$ ve $p<0,01$ değeri kabul edilmiştir.

\section{BULGULAR}

Tedavi sırasında alınan bazı hava örneklerinde inkübasyon sonrasında maya-mantar oluşumu sebebiyle CFU sayımı yapılamaması nedeniyle tedavi sırasında alınan hava örnekleri değerlendirme dışı bırakıldı. Total aerobik mezofilik bakteri sayımının değerlendirildiği bu çalışmada ultrasonik skaler kullanımına bağlı aerosol kontaminasyonu en yüksek değerlerinin tedavi hemen sonrasında görüldüğü tespit edildi $\left(780,143 \pm 130,979 \mathrm{CFU} / \mathrm{m}^{3}\right)$ (Tablo 1).

Tablo 1.

Ultrasonik skaler kullanımı sonrası farklı zaman aralıklarında alınan hava örneklerindeki CFU sayıları

\begin{tabular}{|lcc|}
\hline Ölçüm Zamanı & Ortalama CFU/m & $\begin{array}{l}\text { Standart } \\
\text { Hata(sh) }\end{array}$ \\
\hline Tedavi öncesi & 230,429 & 60,458 \\
\hline $\begin{array}{l}\text { Tedavi hemen } \\
\text { sonrası }\end{array}$ & 780,143 & 130,979 \\
\hline $\begin{array}{l}\text { Tedaviden15 dk } \\
\text { sonra }\end{array}$ & 680,857 & 160,796 \\
\hline $\begin{array}{l}\text { Tedaviden } 30 \mathrm{dk} \\
\text { sonra }\end{array}$ & 640,857 & 100,037 \\
\hline $\begin{array}{l}\text { Tedaviden } 45 \mathrm{dk} \\
\text { sonra }\end{array}$ & 630,857 & 160,241 \\
\hline $\begin{array}{l}\text { Tedaviden } 60 \mathrm{dk} \\
\text { sonra }\end{array}$ & 550,571 & 80,992 \\
\hline $\begin{array}{l}\text { Tedaviden } 75 \mathrm{dk} \\
\text { sonra }\end{array}$ & 380 & 70,862 \\
\hline $\begin{array}{l}\text { Tedaviden } 90 \mathrm{dk} \\
\text { sonra }\end{array}$ & 320,571 & 80,88 \\
\hline $\begin{array}{l}\text { Tedaviden } 105 \\
\text { dk sonra }\end{array}$ & 440,143 & 110,124 \\
\hline $\begin{array}{l}\text { Tedaviden } 120 \\
\text { dk sonra }\end{array}$ & 280,143 & 20,703 \\
\hline
\end{tabular}

Tedavi hemen sonrasındaki CFU miktarının tedavi öncesine göre istatistiksel olarak anlamlı şekilde yüksek olduğu bulundu $(p=0,009<0,01)$. Tedavi sonrasından itibaren CFU miktarının kademeli olarak azaldığı görüldü. Bununla beraber tedavi hemen sonrası, tedaviden $15 \mathrm{dk}, 30 \mathrm{dk}, 45 \mathrm{dk}$ ve $60 \mathrm{dk}$ sonra alınan örneklerdeki CFU miktarları arasında istatistiksel olarak anlamlı fark olmadığı görüldü $(p>0,05)$. 
Tedavi öncesi CFU miktarı, tedaviden $15 \mathrm{dk}, 30 \mathrm{dk}$ ve 60 dk sonraki CFU miktarlarından istatistiksel olarak anlamlı şekilde düşük bulundu $(p<0,05)$. Tedavi öncesi CFU miktarı ve tedaviden sonra $75 \mathrm{dk}, 90 \mathrm{dk}$ ve $120 \mathrm{dk}$ sonraki CFU miktarları arasında istatistiksel olarak anlamlı fark olmadığı görüldü $(p>0,05)$.

Tedaviden $60 \mathrm{dk}$ sonra ise ortamdaki CFU kontaminasyonunun istatistiksel olarak anlamlı şekilde azaldığı görüldü. Tedaviden $60 \mathrm{dk}$ sonraki CFU miktarının $75 \mathrm{dk}$ ve $90 \mathrm{dk}$ ve $120 \mathrm{dk}$ sonrakine göre istatistiksel olarak anlamlı şekilde yüksek olduğu görüldü $(p<0,05)$.

Tedaviden $75 \mathrm{dk}$ sonra, tedaviden $90 \mathrm{dk}, 105 \mathrm{dk}$ ve 120 dk sonra alınan örneklerdeki CFU miktarları arasında istatistiksel olarak anlamlı fark olmadığı görüldü $(p>0,05)$.

Tedaviden 105 dk sonra CFU kontaminasyonunda bir artış görülse de, tedavi sonrası $105 \mathrm{dk}$ sonra CFU miktarı ile tedaviden $90 \mathrm{dk}$ ve $120 \mathrm{dk}$ sonrası CFU miktarı arasında istatistiksel olarak anlamlı fark olmadığı görüldü $(p>0,05)$.

Tedavi hemen sonrası CFU miktarının tedaviden $75 \mathrm{dk}$ $(p<0,05), 90 \mathrm{dk}(p<0,01)$ ve $120 \mathrm{dk}$ sonrasındakine göre $(p<0,01)$ istatistiksel olarak anlamlı şekilde yüksek olduğu görüldü.

Tedaviden $15 \mathrm{dk}$ sonraki CFU miktarı tedaviden $75 \mathrm{dk}$, $90 \mathrm{dk}$ ve $120 \mathrm{dk}$ sonrakine göre istatistiksel olarak anlamlı şekilde yüksek bulundu $(p<0,05)$.

Tedaviden $30 \mathrm{dk}$ sonraki CFU miktarı tedaviden $75 \mathrm{dk}$, $90 \mathrm{dk}$ ve $120 \mathrm{dk}$ sonrakine göre istatistiksel olarak anlamlı şekilde yüksek bulundu $(p<0,05)$.

Tedavi öncesi ve tedavi sonrası farklı zaman aralılarında alınan hava örneklerindeki CFU miktarlarının istatistiksel olarak değerlendirilmesi Şekil 1'de özetlenmiştir.

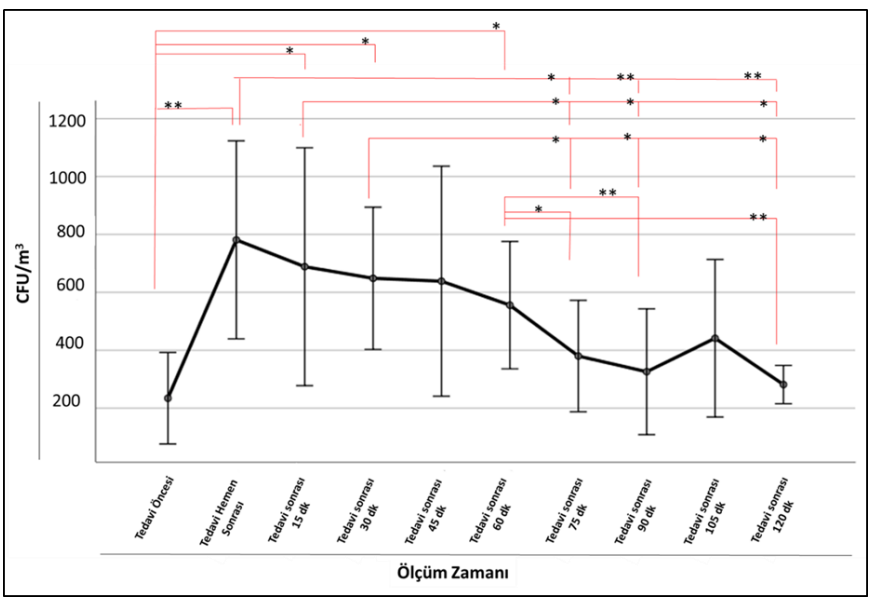

Şekil 1

Tedavi öncesi ve tedavi sonrası farklı zaman aralılarında alınan hava örneklerindeki CFU miktarlarının değerlendirilmesi

$*_{p}<0,05, * * p<0,01$ standart hata barlarl \%95 Confidence Interval(CI)

\section{TARTIŞMA}

Ağızda uygulanan hemen hemen her dental işlemde aerosol ve bioaerosol oluşumu meydana gelmektedir. Yapılan bir in vitro çalışmada soğutma suyu kullanılmadan ultrasonik skaler kullanımında dahi aerosolize partiküllerin ortama saçılığı raporlanmıştır. ${ }^{14}$ Aerosoller solunum yolu enfeksiyonları, göz ve deri rahatsızlıkları, tüberküloz ve lejyonelloz gibi enfeksiyoz hastalıkların oluşumunda etken olmaktadır. Ayrıca hepatit B ve influenza gibi viral enfeksiyonların yayılımında da önemlidir. ${ }^{8,10} \mathrm{Bu}$ çalışmanın sonuçları ultrasonik skaler kullanılarak yapılan başlangıç periodontal tedavi işlemi sonrasında aerosol kontaminasyonunun önemli ölçüde yükseldiğini ortaya koymaktadır. Bakteriyel aerosol kontaminasyonunun tedavi hemen sonrasında pik değerlere ulaştığı ve istatistiksel olarak anlamlı şekilde tedavi bitiminden sonra 60 dk'ya kadar ortamda kaldığı sonucuna varılmışıı. Her ne kadar CFU miktarlarının pik değerlere ulaştıktan sonra genel olarak azaldığı görülse de bu azalmanın tedavi sonrası $60 \mathrm{dk}$ ' ya kadar istatistiksel olarak anlamlı olmadığı, tedavi bitiminden $60 \mathrm{dk}$ sonra ise aerosol kontaminasyonunun istatistiksel olarak anlamlı şekilde azaldığı bulunmuştur. Tedavi sonrası $75 \mathrm{dk}$ ve sonrasında ise tedavi öncesi kontaminasyon değerlerine benzer kontaminasyon değerleri görülmektedir (Şekil 1 ve Tablo 1). Dental işlemler sonrası aerosol kontaminasyonun artı̧ göstermesi literatürdeki birçok çalışmanın sonuçları ile uyumludur. ${ }^{4,5,15}$

Dental işlemlere bağlı aerosol kontaminasyonunun değerlendirilmesindeki en önemli sorunlardan biri hava örneklemesinin standardizasyonun sağlanması olarak ön plana çıkmaktadır. Çeşitli çalışmalarda hava örnekleme cihazının yeri ve örnekleme süresinin farklılık gösterdiği görülmektedir. ${ }^{5,15,17} \mathrm{Bu}$ çalışmada ise hava örnekleme cihazı hasta ağzından ve yerden $100 \mathrm{~cm}$ uzaklığa yerleştirilmiş ve hava örneklemesi 1 dk (100lt/dk sabit debi) süreli yapılmıştır. Bu uzaklıklar çalışmada kullanılan hava örnekleme cihazı kullanılarak yapılan bir ön çalışma sonucunda elde edilmiştir ve Pasquarella ve ark'nın bu çalışmasıyla uyumludur. ${ }^{18} \mathrm{Bu}$ çalışmada tedavi öncesi ve sonrasında elde edilen CFU değerlerinin literatürdeki bazı çalışmaların çok üzerinde olduğu görülmektedir. ${ }^{5,15,19} \mathrm{Bu}$ çalışmalarda nispeten uzun örneklem süreleri olduğu görülmektedir. Uzun örneklem süreleri hava örnekleme cihazının içerisine yerleştirilen besiyerinin zamanla kuruması ve canlılık oluşturma potansiyelinin azalmasına veya aerosol kontaminasyonun pik değerlerinin kaçırılmasına neden olabilmektedir. ${ }^{13,17}$ Bu çalışmada $1 \mathrm{dk}$ gibi kısa süreli bir örnekleme yapılmış ve CFU değerlendirmesi buna göre yapılmıştır. Dental işlemler sonrası aerosollerin davranış biçimleri çeşitli araştırıcılar 
tarafından çalışımıştır. Veena ve ark'nın ${ }^{20}$ yaptığı in vitro çalışmada aerosollerin saçılma karakteristikleri araştırılmış ve işlemden $30 \mathrm{dk}$ sonra parçacıkların ortamda bulunduğu ve $60 \mathrm{dk}$ sonrasında herhangi bir kontaminasyon bulunmadığı sonucuna varmışlardır. Ayrıca bu çalışmada kullanılan filtreler $30 \mathrm{dk}$ aralıklarla değiştirilmiş ve ağız içi ortamın taklit edilmesi amaçı çeşitli boyayıcı ajanlar kullanılmıştır. ${ }^{20}$ Iki hastanın dahil edildiği bir pilot çalışmada ise $15 \mathrm{dk}$ örnek alma süreleri ile hava örnekleri alınmış ve en az 20 dk aerosollerin havada asılı kaldığı raporlanmıştır ${ }^{21}$. Grenier ve ark yaptığı çalışmada ise 30 dk' lık örnek alma süreleri ile örnekler alınmış ve tedaviden $120 \mathrm{dk}$ sonrasında ortam havasının başlangıç koşullarına döndüğü bulunmuştur. Ancak bu çalışmada tedavi sonrasında ara zamanlarda ölçümlerle ilgili veri bulunmamaktadır. ${ }^{5}$ Bizim çalışmamızda ise tedavi sonrası 60 dk' ya kadar tedavi öncesine göre istatistiksel olarak anlamlı şekilde yüksek aerosol kontaminasyon seviyeleri görüldü ve kontaminasyonun tedaviden $60 \mathrm{dk}$ sonrasında istatistiksel olarak anlamlı şekilde azaldığı bulundu. Çalışmanın sonuçlarına göre ortam havasının tedaviden $75 \mathrm{dk}$ sonrasında tedavi öncesi değerlere döndüğü söylenebilir. Kısa örneklem sürelerinin daha sık zaman aralıklarında ve besiyerinin canlılık oluşturma potansiyelini azaltmadan hava örnekleri alınmasında yardımcı olduğu düşünülmektedir. Değerlendirmemizin sınırları içerisinde literatürde dental işlemler sonrası kısa zaman aralıkları ile aerosol kontaminasyonunun monitorizasyonuna yönelik çalışma bulunamamıştır. Bu çalışmanın bu konuda literatüre katkı sağlayacağı düşünülmektedir.

Dental işlemler sırasındaki aerosol kontaminasyonu havalandırma, nem, sıcaklık, farklı ağız içi durumlar, dental personel hareketleri gibi birçok etkene bağlı olarak değişiklik gösterebilmektedir. ${ }^{12,15}$ Aerosol kontaminasyonun monitorizasyonun dış etkenlere kapalı ve giriş çıkışlara kapatılmış, izole bir tedavi odasında yapılmasının bu açıdan önemli olduğu düşünülmektedir. Bu çalışmada ayrıca işlem sonrası ortaya çıkan aerosol kontaminasyonunda etkili olabileceği düşüncesiyle hastaların ağız içi kondisyonlarının benzer olması sağlanmış, plak indeksi 1-2 arasında olan ve aktif çürük lezyonu bulunmayan hastalar çalışmaya dahil edilmiştir. Tedaviden 105 dk sonra yapılan ölçümlerde aerosol kontaminasyonunda 90 dk'ya göre artış olduğu görülmektedir. Bu durumun hava akımındaki değişikliklere bağlı olarak oluşmuş olabileceği düşünülmektedir. Nitekim tedavi sonrası $75 \mathrm{dk}, 90 \mathrm{dk}, 105 \mathrm{dk}$ ve $120 \mathrm{dk}$ sonraki kontaminasyon seviyelerinde istatistiksel anlamlı fark bulunmamaktadır. Bu durumun sonuç üzerinde etkili olmadığı düşünülmektedir. İç ortamlarda hava-yolu kaynaklı enfeksiyon yayılımının önlenmesi özellikle diş hekimliği gibi medikal alanlarda daha fazla önem kazanmaktadır. Dental kliniklerde gerek hasta gerek dental perdonel kaynaklı hava yoluyla bulaş riski mevcuttur. Fırsatçı patojenler de içeren dental aerosoller özellikle immun sistemi zayıf veya baskılanmış kişilerde ciddi tehlike olarak kabul edilmelidir. ${ }^{5}$ ciddi tehlike olarak kabul edilmelidir. ${ }^{5}$ Duyarlı hastaları tanımlamak ve gerekli koruyucu önlemlerin alınması hekimin sorumluluğu altındadır. ${ }^{22}$ Dental işlemler sonrası oluşan aerosol kontaminasyonunun azaltılmasında yüksek emiş gücüne sahip, geniş çaplı dental vakumların kullanımının ve preoperatif olarak klorheksidin içerikli ağız gargaralarının kullanımının etkili olduğu gösterilen çalışmalar mevcuttur. 4,8,23 Maske, eldiven veya gözlük gibi yüz koruyucuların kullanılması da operasyon alanıyla direkt teması önlemektedir. ${ }^{15}$ Ancak burada en iyi kalitedeki maskelerin dahi \%65-90 arasında koruma sağladığını ve maske yerine yeterli sevide oturmazsa etkisinin daha da az olacağını söylemek gerekmektedir. ${ }^{8} \mathrm{Bu}$ çalışmada işlem sonrası kendi haline bırakılan aerosollerin 60 dk'ya kadar ortamda kalmaya devam ettiği görülmektedir. Bu nedenle işlem bittikten hemen sonra maskenin çıkarılmaması aerosol kontaminasyonunun azaltılmasında etkili olabilir. Ayrıca çapraz enfeksiyonun yayılımının önlenlemesi için tüm dental personelin kişisel hijyenine daha fazla önem vermesinin sağlanması gerekmektedir. Aerosol kontaminasyon seviyelerinin yüksek olduğu işlem hemen sonrası dönemde dental tedavi kliniklerinin havalandırması da kontaminasyonunun azaltılmasında etkili olabilmektedir. HEPA filtrelerin kullanımı ve ultraviyole ışıklarla ortam dezenfeksiyonunun yararlı olduğuna dair çalışmalar da mevcuttur. ${ }^{7,20}$ Mikrobyal kontaminasyonun total bakteriyel kontaminasyon üzerinden gösterilmesi bu çalışmanın limitasyonları arasında yer almaktadır. Tüm dental personel ve hastalar için odak noktası güvenli bir çalışma ortamı oluşturulmasıdır. Ağız gibi çok dinamik bir çalışma ortamında enfeksiyon yayılımının önlenmesi daha fazla önem kazanmaktadır. Aerosol kontaminasyonunun ortamda bulunma dinamiklerinin belirlenmesi ve öğrenilmesinin enfeksiyon kontrolünde önemli bir adım olduğu düşünülmektedir. Ayrıca bu çalışmanın günümüzde devam eden Covid-19 pandemisinin diş hekimliği uygulama alanlarına etkisi ve korunma yollarının araştırıldığı ileri çalışmalara da katkıda bulunacağı düşünülmektedir.

\section{SONUÇ}

Periodontal tedavi sırasında ultrasonik skaler kullanımına bağlı olarak ortam kontaminasyonunda ciddi oranda artış meydana gelmektedir. Kontaminasyonun boyutu ağız içi kondisyonlar, çevresel etkenler ve çalışmanın şekli gibi değişik etkenlere bağlı olsa da bu çalışmanın sonuçlarına göre ortam kontaminasyonu tedavi bitiminden sonra da uzun süre devam etmektedir. Diş hekimliği pratiğinde tedavi sürecinde ve enfeksiyon kontrolünde bu çalışmanın sonuçlarının katkı sağlayabileceği düşünülmektedir. 


\section{KAYNAKLAR}

1. Van der Weijden G, Timmerman M. A systematic review on the clinical efficacy of subgingival debridement in the treatment of chronic periodontitis. Journal of Clinical Periodontology. 2002;29:55-71.

2. Oda S, Nitta H, Setoguchi T, Izumi Y, Ishikawa I. Current concepts and advances in manual and power-driven instrumentation. Periodontology 2000. 2004;36(1):4558.

3. Tunkel J, Heinecke A, Flemmig TF. A systematic review of efficacy of machine-driven and manual subgingival debridement in the treatment of chronic periodontitis. Journal of clinical periodontology. 2002;29:72-81.

4. Timmerman M, Menso L, Steinfort J, Van Winkelhoff A, Van Der Weijden G. Atmospheric contamination during ultrasonic scaling. Journal of clinical periodontology. 2004;31(6):458-62.

5. Grenier D. Quantitative analysis of bacterial aerosols in two different dental clinic environments. Appl Environ Microbiol. 1995;61 (8):3165-8.

6. Harrel SK, Barnes JB, Rivera-Hidalgo F. Reduction of aerosols produced by ultrasonic sealers. Journal of periodontology. 1996;67(1):28-32.

7. Micik RE, Miller RL, Mazzarella MA, Ryge G. Studies on dental aerobiology: I. Bacterial aerosols generated during dental procedures. Journal of dental research. 1969;48(1):49-56 .

8. Harrel SK, Molinari J. Aerosols and splatter in dentistry: a brief review of the literature and infection control implications. The Journal of the American Dental Association. 2004;135(4):429-37.

9. Sotiriou M, Ferguson SF, Davey M, Wolfson JM, Demokritou P, Lawrence J, et al. Measurement of particle concentrations in a dental office. Environmental monitoring and assessment. 2008;137(1-3):351.

10. Miller R. Generation of airborne infection... by high speed dental equipment. The Journal of the American Society for Preventive Dentistry. 1976;6(3):14.

11. Willeke K, Macher J, editors. Bioaerosols: assessment and control. Cincinnati, $\mathrm{OH}$ : American Conference of Governmental Industrial Hygienists; 1999.

12. Burger $\mathrm{H}$. Bioaerosols: prevalence and health effects in the indoor environment. Journal of Allergy and Clinical Immunology. 1990;86(5):687-701.

13.Pasquarella $C$, Pitzurra $O$, Savino A. The index of microbial air contamination. Journal of hospital infection. 2000;46(4):241-56.

14. Harrel SK, Barnes JB, Rivera-Hidalgo F. Aerosol and splatter contamination from the operative site during ultrasonic scaling. The Journal of the American Dental Association. 1998;129(9):1241-9.

15. Hallier C, Williams DW, Potts AJC, Lewis MAO. A pilot study of bioaerosol reduction using an air cleaning system during dental procedures. British dental journal. 2010;209(8):E14.
16. Leggat PA, Kedjarune U. Bacterial aerosols in the dental clinic: a review. International Dental Journal. 2001;51(1):39-44.

17.Bennett A, Fulford M, Walker J, Bradshaw D, Martin M, Marsh P. Occupational health: Microbial aerosols in general dental practice. British dental journal. 2000;189(12):664.

18.Pasquarella C, Veronesi L, Napoli C, Castiglia $\mathrm{P}$, Liguori G, Rizzetto $\mathrm{R}$, et al. Microbial environmental contamination in Italian dental clinics: A multicenter study yielding recommendations for standardized sampling methods and threshold values. Science of the total environment. 2012;420:289-99.

19.Dutil S, Mériaux A, de Latrémoille M-C, Lazure L, Barbeau J, Duchaine C. Measurement of airborne bacteria and endotoxin generated during dental cleaning. Journal of occupational and environmental hygiene. 2008;6(2):121-30.

20. Veena H, Mahantesha S, Joseph PA, Patil SR, Patil SH. Dissemination of aerosol and splatter during ultrasonic scaling: a pilot study. Journal of infection and public health. 2015;8(3):260-5.

21. Chuang $\mathrm{C}-\mathrm{Y}$, Cheng $\mathrm{H}-\mathrm{C}$, Yang S, Fang W, Hung P-C, Chuang S-Y. Investigation of the spreading characteristics of bacterial aerosol contamination during dental scaling treatment. Journal of Dental Sciences. 2014;9(3):294-6.

22. Al Maghlouth A, Al Yousef $\mathrm{Y}$, Al Bagieh N. Qualitative and quantitative analysis of bacterial aerosols. J Contemp Dent Pract. 2004;5(4):91-100.

23.Gupta G, Mitra D, Ashok K, Gupta A, Soni S, Ahmed $S$, et al. Efficacy of preprocedural mouth rinsing in reducing aerosol contamination produced by ultrasonic scaler: a pilot study. Journal of periodontology. 2014;85(4):562-8.

\section{Yazışma Adresi:}

\section{Sefa AYDINDOĞAN}

Selçuk Üniversitesi

Diş Hekimliği Fakültesi, Periodontoloji AD

42250, Konya, Türkiye

Tel : : +90 5392285277

E Posta: aydindogansefa@gmail.com 